Article

\title{
Sustainable Livelihoods of Township Small, Medium and Micro Enterprises towards Growth and Development
}

\author{
Stella Bvuma and Carl Marnewick * (1) \\ College of Business and Economics, Department of Applied Information Systems, University of Johannesburg, \\ Johannesburg 2006, South Africa; stellab@uj.ac.za \\ * Correspondence: cmarnewick@uj.ac.za
}

Received: 17 February 2020; Accepted: 30 March 2020; Published: 14 April 2020

check for updates

\begin{abstract}
In South Africa, small, medium, and micro enterprises (SMMEs) have been recognized as the critical driving force to alleviate some economic challenges that the country faces. The challenges, such as the alleviation of poverty and the unemployment rate, can be addressed by policies that encourage SMME developments and sustainability. The historical background of SMMEs in South Africa has left them operating in various locations, such as cities and townships. There is a growing concern of the lack of information and communications technology (ICT) adoption by SMMEs, in particular those operating in townships. The aim of this study was to develop an ICT adoption framework using the sustainability livelihood framework (SLF) to encourage ICT adoption and improve the livelihood of township SMMEs. This study used the sustainable livelihood framework (SLF) to explore the broader socio-economic contents of the township SMMEs on human, social, financial, and physical and natural resource-based assets that enable the poor to enhance their capabilities and reduce their vulnerabilities. This study deployed a qualitative exploratory research. A sample of 21 SMME owners/managers operating in Soweto was used, and data were collected using in-depth interviews and observations. The study revealed township SMMEs are complex and dynamic and need various interventions in order for them to be sustainable. The SLF for township SMMEs can be used as a guideline for SMME owners/managers and policy makers when formulating ICT adoption policy.
\end{abstract}

Keywords: information communication technology (ICT); sustainable livelihood approach (SLA); sustainability livelihood framework (SLF); South Africa

\section{Introduction}

Small, medium, and micro businesses (SMMEs) play an important role in the development of an economy. Successful economies around the world have acknowledged the positive contribution that SMMEs play towards growth and development of the economy. In African countries, where many economies are informal, SMMEs are a vehicle facilitating individuals' participation in the economy. As such, SMMEs form a critical backbone of many of the African economies [1-3]. Furthermore, as in many socio-economic establishments in Africa, South African SMMEs operate in different environments that are located in cities as well as townships. Although the literature reveals that SMMEs in South Africa may generally share common challenges, such as poor access to finance, they also have unique challenges that may be influenced by their environment and historical background. This study argues that township SMMEs are dynamic and may face unique challenges as compared to SMMEs operating in the cities. Township SMMEs are unique and have different attributes that are influenced by their environment and their historical background. This study aims to explore and understand 
the dichotomy that exists between SMMEs operating in cities and those operating in townships. The need to understand challenges faced by township SMMEs with regard to ICT adoption may lead to the SMMEs' sustainability and improving their livelihood. The motivation for this study is based on the lack of information on ICT adoption by township SMMEs and the factors that affect their adoption or non-adoption. In order for township SMMEs to fully participate in the economy, develop, and grow, there is a need to have an in-depth understanding of the factors affecting their ICT adoption and formulate guidelines for their sustainability. Failure to understand this phenomenon may contribute to the increase in unemployment that the country is currently facing, and the township SMMEs may be left behind in competing in the digital economy. The adoption of ICTs by township SMMEs can contribute positively towards the South African economy, address challenges such as unemployment, and create platforms for township SMMEs to gain competitive advantage and participate in the global economy. Currently, there are limited empirical studies on ICT adoption by township SMMEs, and no ICT adoption sustainability livelihood framework for township SMMEs. An ICT adoption sustainability livelihood framework could provide SMME owners/managers and policymakers with guidance on what strategies to put in place to support and guide township SMMEs.

The adoption of ICT can be a driving force for addressing socio-economic challenges faced by South Africa, such as poverty alleviation [4,5].

The literature suggests that the use of the sustainability livelihood framework (SLF) could be deployed to explore how ICT can contribute to people's livelihood and, in this case, township SMMEs [6-8]. Therefore, this study is focused on township SMMEs and their contribution to the livelihood of the township economy through the adoption of ICT.

However, various studies have been conducted around SMMEs in South Africa, precluding the township context [9-13]. Reference [14] agreed that literature on small businesses focuses on other SMME contexts as a whole, while far less research has focused on the township SMME context. Questions such as, "why are township SMMEs are not adopting ICTs?" or, "why are they precluding other types of ICTs?" need to be examined in real contextual settings in order to understand their true answers. The success of ICT adoption by township SMMEs will facilitate an increased contribution towards growth, development, and sustainability, which may lead to the reduction of unemployment in the South African economy. The adoption of ICT will enable township SMMEs to compete with larger enterprises and positively contribute to the township economy. Literature has shown the positive impact that ICT adoption can have on SMMEs, thus it is of utmost importance that township SMMEs are not precluded in the adoption of ICT [15]. Therefore, the research problems are determined as follows: there is a lack of research studies on factors affecting the ICT adoption by township SMMEs, and there is no ICT adoption sustainability livelihood framework for township SMMEs.

In order to clearly realise the research aim, this study implements a stepwise research process by firstly conducting literature review on ICT adoption by SMMEs. Furthermore, by examining the distinct differences between SMMEs operating in townships as oppose to those operating in the cities. This is necessary for coming up with guidelines and interventions directed towards policy formulation of township SMMEs' sustainability. Secondly, from the literature review conducted the study design is conceptualised and the key focus solidified, given the gaps identified in the literature. Thirdly, an empirical study is conducted on SMMEs in the Soweto township areas of Gauteng Province. Fourthly, upon critical analysis of the results of the empirical study, a sustainability livelihood framework for adopting ICTs by the SMMEs in townships is conceptualised.

\subsection{Historical Background of Township SMMEs}

The history of township SMMEs in South Africa dates back to the apartheid era, the period during which black people were prohibited from owning businesses and faced prosecution for engaging in any business activity $[16,17]$. Townships experienced segregation in terms of housing, education, health, and libraries, among others [18]. Townships, often referred to as urban residential areas, were formed for the Black population, usually beyond city limits. By contrast, the White population resided 
in suburbs or cities. Generally, every city has at least one township, and often several townships, associated with it.

The understanding of townships and cities provides guidance on the development and growth of SMMEs. According to [19], the main differences between townships and cities in South Africa tend to be bordering on socio-economic parameters. With reference to Johannesburg, the wealthy live to the north of the city centre in the northern suburbs, while the poor live to the south and on the fringes of the city in townships. Reference [20] agree that the environments are not the same; the issues affecting SMMEs can be technological, socio-economic, or as a result of perceptions based on the owners' lived experience. According to reference [21], many of South Africa's township areas exist below the subsistence levels and remain impoverished because they lack access to basic infrastructure, thus lagging behind on gaining economic growth and development. The literature shows that even after becoming a democratic country in 1994, South Africa still seems to have well-structured geographical inequalities and challenges hindering the growth of township profile SMMEs [22]). The legacy of apartheid resulted in challenges such as policies that were geared towards exclusion and lack of access to resources, exclusion from participating in the small business sector, and segregation of townships and cities $[23,24]$.

The township SMME economy prior to 1994 was not included in government policies because many of them were disregarded by the apartheid government. In line with the political disinterest, SMMEs were wiped off the research agenda of most business schools and university commerce departments [25]. According to [26], the larger enterprises were more likely seen as potential enablers for employment creation and economic growth, which were mainly White owned and operated in the cities. The realisation of the SMME sector only occurred in the 1970s and 1980s. The South African government initiated the Institution of Small Business Development Corporation (SBDC) in the early 1980s in order to provide support to SMMEs. In 1995, the government further initiated the design of the policy framework to be inclusive of the entire classification of SMMEs and gave them the opportunity to participate in the economy. This was the government's National Strategy for Development and Promotion (NSDP) of small businesses (National Framework on Sustainable Development (NFSD) (2008). The NSDP's overall objective was to create an enabling environment for SMME growth in the country as a way of addressing basic inequalities in the economy. Despite the aforesaid political will and interventions, SMMEs seem to still be facing acute challenges preventing them from effectively participating in the economy.

\subsection{SMME Classifications}

There is no global consensus of what constitutes SMMEs. SMMEs are classified into formal, informal, and survivalist and are influenced by the context in which the small business is located. In South Africa, specifically, SMMEs have been classified with reference to the sectors or environments in which they operate. The classification of SMMEs by virtue of the environment in which they operate makes it complicated to globalise the challenges they face. It can thus be posited that the different sectors and environments subject the SMMEs to different contextual challenges and therefore expose them to different levels of appetite for the adoption of ICTs.

It is necessary to define an SMME within the defined limits as set out in the policies of that country. SMME challenges need to be addressed with careful attention in order to guide policymakers. For example, the poor infrastructure in townships may hinder township SMMEs from bringing attention to their needs.

\subsection{SMMEs in the South African Context}

The South African National Small Business (NSB) Act 102 of 1996 defines a small business as a separate entity that can be within any sector or sub-sector of the economy and which can be classified as a micro-enterprise, a very small enterprise, a small enterprise, or a medium enterprise [27]. The NSB Amendment Acts of 2003 and 2004 further define an SMME as a distinct business entity managed 
by one or more persons which must meet certain specified criteria. Table 1 illustrates the definition of SMMEs used by the NSB Act of South Africa.

Table 1. Definition of small, medium, and micro enterprises (SMMEs) according to the National Small Business (NSB) Act of South Africa [26].

\begin{tabular}{|c|c|c|c|}
\hline Enterprise Size & Number of Employees & $\begin{array}{c}\text { Annual Turnover in South } \\
\text { African Rand }\end{array}$ & $\begin{array}{l}\text { Gross Assets, Excluding } \\
\text { Fixed Property }\end{array}$ \\
\hline Medium & $\begin{array}{l}\text { Fewer than } 100 \text { to } 200 \text {, } \\
\text { depending on industry }\end{array}$ & $\begin{array}{l}\text { Less than R4 million to R50 m, } \\
\text { depending on industry }\end{array}$ & $\begin{array}{l}\text { Less than } \mathrm{R} 2 \mathrm{~m} \text { to } \mathrm{R} 18 \mathrm{~m} \text {, } \\
\text { depending on industry }\end{array}$ \\
\hline Small & Fewer than 50 & $\begin{array}{l}\text { Less than } \mathrm{R} 2 \mathrm{~m} \text { to } \mathrm{R} 25 \mathrm{~m} \text {, } \\
\text { depending on industry }\end{array}$ & $\begin{array}{l}\text { Less than } \mathrm{R} 2 \mathrm{~m} \text { to } \mathrm{R} 4.5 \mathrm{~m} \text {, } \\
\text { depending on industry }\end{array}$ \\
\hline Very Small & $\begin{array}{l}\text { Fewer than } 10 \text { to } 20 \text {, } \\
\text { depending on industry }\end{array}$ & $\begin{array}{l}\text { Less than R200,000 to R500,000, } \\
\text { depending on industry }\end{array}$ & $\begin{array}{l}\text { Less than R150,000 to R500,000, } \\
\text { depending on industry }\end{array}$ \\
\hline Micro & Fewer than 5 & Less than R150,000 & Less than R100,000 \\
\hline
\end{tabular}

It becomes evident that within the South African context, an SMME is classified as a business which has no more than 200 employees and certain turnover criteria based on the sector. Thus, if a business has fewer than 200 employees, but the revenue is more than the indicated value per industry, reference [28]'s argument that SMMEs are not only based on size but also their complexity would appear to have some merit. It is thus coherent to posit that a clear definition of an SMME is a multi-dimensional function considering a lot of variables given the context in which a perceived SMME operates.

Other studies conducted in South Africa have also grouped these enterprises and referred to them as small businesses [29,30]:

- Survivalist: The income generated is below the poverty line, poor capital is invested, and there is hardly any asset. They are often referred to as hawkers, vendors, and subsistence farmers without much training;

- Micro: They lack formality in terms of registration. They employ between one and five employees, they include spaza/tuck shops, minibus taxis, and they may be on household premises;

- Very small: They may employ fewer than 10 employees. These include artisans (electricians, plumbers) and other professionals. However, this does not include sectors such as mining and construction, manufacturing and electricity, but does include professionals such as artisans, electricians, and plumbers;

- Small: They are seen as more established compared to the very small businesses and may be formal and registered businesses, owner-managed but with more complex structures;

- Medium: They employ a maximum of 100 or 200 people for various sectors, which includes the mining, electricity, manufacturing, and construction sector, in which the maximum is 20 employees. They operate on fixed premises with formal requirements.

The survivalist, micro, and very small enterprises in South Africa are often grouped together and referred to as "small businesses". While many countries do not have micro-businesses as part of the small business definition, this indicates the diversity of the small business definitions, particularly in South Africa, because the micro-businesses are also classified as survivalists [31]. However, the literature points out that SMMEs can be classified as small businesses. Other studies conducted in South Africa have also grouped these enterprises and referred to them as small businesses $[29,30]$ as a result of these small businesses sharing common challenges [32].

This study groups the classifications of survivalist, micro, very small, small, and medium businesses together to refer to them as SMMEs, which means small businesses. The study adopts the new definition as described by the South African government in 2019. According to the South African Government Gazette [26], the new definition of SMMEs uses two proxies (employees and annual turnover) and excludes the original third proxy (total gross asset value) [26]. The study thus 
defines an SMME as any small business regardless of its registration under law or tax and it can be any entity or organisation, which includes any person conducting small business activities in any sector.

\subsection{Challenges Faced by Township SMMEs}

An informal business is a livelihood strategy for poor people in both the developing and the developed world [33]. However, most township SMMEs do not grow in size and develop like those in the formal sector in the cities [34]. Reference [35] argued that while some informal businesses in inner cities grow, those in townships mainly just survive, i.e., they only make money to meet their family's daily needs. Reference [36] stated that the challenges that SMMEs face may be internal or external, and they have a huge impact on the survival and the sustainability of the business. Since township SMMEs operate in environments that differ from the SMMEs operating in the cities, they have unique challenges. Some of the challenges are: skills and knowledge [37]; lack of finance, lack of relevant information on government support, crime, and absent infrastructure [38]; lack of support from stakeholders, lack of legal knowledge, lack of funding, lack of business acumen, and poor technological skills [39]; lack of business acumen [40]; lack of management skills, finance and obtaining credit, access to markets, and developing relationships with customers [19]; lack of education, lack of training, and inadequate government support [41]; ICT education, lack of ICT awareness [14]; poor management skills, access to funding, lack of infrastructure, and poor government support [42]; competition, product cost, high inventory cost, high rental cost, and poor marketing of the business [43]; need for marketing, financial training, management training, and collaboration between government and stakeholders to provide adequate training [13]; lack business sustainability skills [44]; and lack of information, lack of resources [36].

Most of these mentioned challenges can be overcome by adopting and streamlining ICT in the business processes of SMMEs. The adoption and use of ICT plays a critical role in facilitating socio-economic development in SMMEs in developing countries [45-47].

\subsection{The Role of Township SMMEs in the Economy}

SMMEs in South Africa play a critical role in the country's economy and contribute between 40 per cent and 41 per cent of the country's GDP and up to 61 per cent of the overall employment in South Africa [48]. According to the review of the 2013 SBP SME Growth Index, the South African National Development Plan (NDP) has set a very ambitious aim of increasing the size of its economy by a minimum of 5.4 per cent a year over 15 years. This initiative is, however, a necessary challenge to engage in, as South Africa's high rate of employment is increasing. The state of employment in South Africa remained unchanged at 43.10 per cent in the third quarter of 2018, from 43.10 per cent in the second quarter of 2018. The employment rate in South Africa averaged 43.21 per cent from 2000 until 2018, reaching a high of 46.17 per cent in the fourth quarter of 2008 and a record low of 41 per cent in the first quarter of 2004 [49], which was partly exacerbated by a chronic shortage of skilled labour. Against this backdrop, the government is aiming to put policies, strategies, and programmes in place, which aim to create an enabling environment for township SMMEs.

Townships SMMEs have the potential to contribute positively to the South African economy. In Gauteng province, the SMMEs created about 150,000 jobs in a single year, and this was as a direct result of government's support to SMMEs [49]. Therefore, it is imperative that township SMMEs receive necessary interventions and support to address many of the challenges faced by the country [11].

The literature has shown that SMMEs are the engine for growth and development. The adoption of ICTs can be a driving force for addressing socio-economic challenges faced by countries, such as poverty alleviation $[4,5]$. The literature revealed that the use of the sustainable livelihoods approach (SLA) could be deployed to explore how ICTs can contribute to people's livelihood [6-8] -in this case, the township SMMEs.

There is a lack of research studies on the sustainability livelihood of township SMMEs and how ICT adoption can contribute towards their growth and development. 


\section{Methodology}

This study was conducted in South Africa, Gauteng Province, Soweto Township. Soweto is the largest township in South Africa, with over 1.516 million people [49], and it is one of the hubs of economic development targeted by the government. Qualitative research provided the researchers with the opportunity to conduct interviews with SMME owners/managers in order to gain an in-depth understanding of their social and cultural context and the factors that affect ICT adoption in their business.

The target population of this study was SMME owners/managers operating in Soweto township in Gauteng province, South Africa. There is no accurate population regarding SMMEs operating in Soweto, as the number of SMMEs may be different at any time given the current prevailing social, economic, and political circumstances. The study included any SMMEs (whether formal or informal) operating in any sector, and these can be regarded as registered or non-registered businesses. However, the larger businesses, such as big retailers (e.g., Pick n Pay, Shoprite, KFC, and McDonalds) operating mainly in township shopping malls were not included in the study. A sample size of 21 was used, applying non-probability purposive sampling. The purposive sample of 21 SMMEs was selected and met the specific criteria, as set out in Table 2, with the main condition that the business must be located and operated in Soweto. This sample was selected because they served the expected purpose of the study [50]. Data were collected through interviews and observations from the township SMMEs owners. Data were analysed through the use of Atlas.ti.

Table 2. Locations/zones of respondents in Soweto.

\begin{tabular}{cccc}
\hline Location/Zone & Medium Business & Small Business & Micro Business \\
\hline Vilakazi & 1 & 1 & 1 \\
Protea South & 1 & 1 & 1 \\
Protea Glen & 1 & 1 & 1 \\
Dobsonville & 1 & 1 & 1 \\
Diepkloof & 1 & 1 & 1 \\
Meadowlands & 1 & 1 & 1 \\
Pimville & 1 & 1 & 7 \\
Total respondents in each zone & 7 & 7 & 1 \\
\hline
\end{tabular}

\subsection{Sustainability Livelihood Approach for ICT Adoption by Township SMMEs}

The purpose of this section is to discuss the application of the Sustainability Livelihood Approach (SLA) in supporting and assessing the adoption of ICT by township SMMEs. The SLA allowed an analysis of the broader socio-economic contents of the township SMMEs owners/managers. According to [51], a holistic examination of how household and socio-economic content in township SMMEs function, as well as a probe into the business factors and reasons behind their failure rate, are necessary. The SLA is defined to better understand the strategies to be used to address poverty through interventions from different stakeholders.

Like many other countries, South Africa is faced with the task of improving the SMME sector and contributing to its growth, development, and sustainability. South African SMMEs do not grow and are not sustainable. They are recorded as having a high failure rate of 75 per cent [52-54]. The SLA can be used when formulating strategies towards poverty alleviation that South Africa continuously battles with. Reference [55] posited that poverty levels in the township are extreme and thus there is a need to have approaches that address the poverty levels in township businesses. Various interventions have been put in place to support township SMMEs. However, township SMMEs are still lacking when it comes to improving livelihoods.

The SLA looks at the core features which are aimed at poverty reduction and improving the vulnerability of township SMMEs. The livelihood approach further seeks to improve the township economy development. SLA makes inquiries for rural and policy development by recognizing the 
complexity of the livelihood strategy. The sustainable livelihoods framework helps in thinking holistically about the things that the poor might be very vulnerable to, the assets and resources that help them thrive and survive, and the policies and institutions that impact on their livelihoods [56].

\subsection{Constructing the Sustainability Livelihood Framework for Township SMMEs}

This section depicts the SLA for township SMMEs with regard to ICT adoption. This study adopted the five capital frameworks of sustainable livelihood, which include human, social, financial, physical, and natural [57-59]. This study added the socio-economic asset as an added denominator for township SMME livelihood.

Figure 1 shows the sustainable livelihoods framework and its various factors, which constrain or enhance livelihood opportunities and show how they relate to each other. The framework provides a way of thinking through the different influences (constraints and opportunities) on livelihoods of township SMMEs, and ensuring that important factors are not neglected [60,61]. The framework shows how, in differing contexts, sustainable livelihoods are geared through access to a various livelihood assets, which are intended in the pursuit of different livelihood strategies.

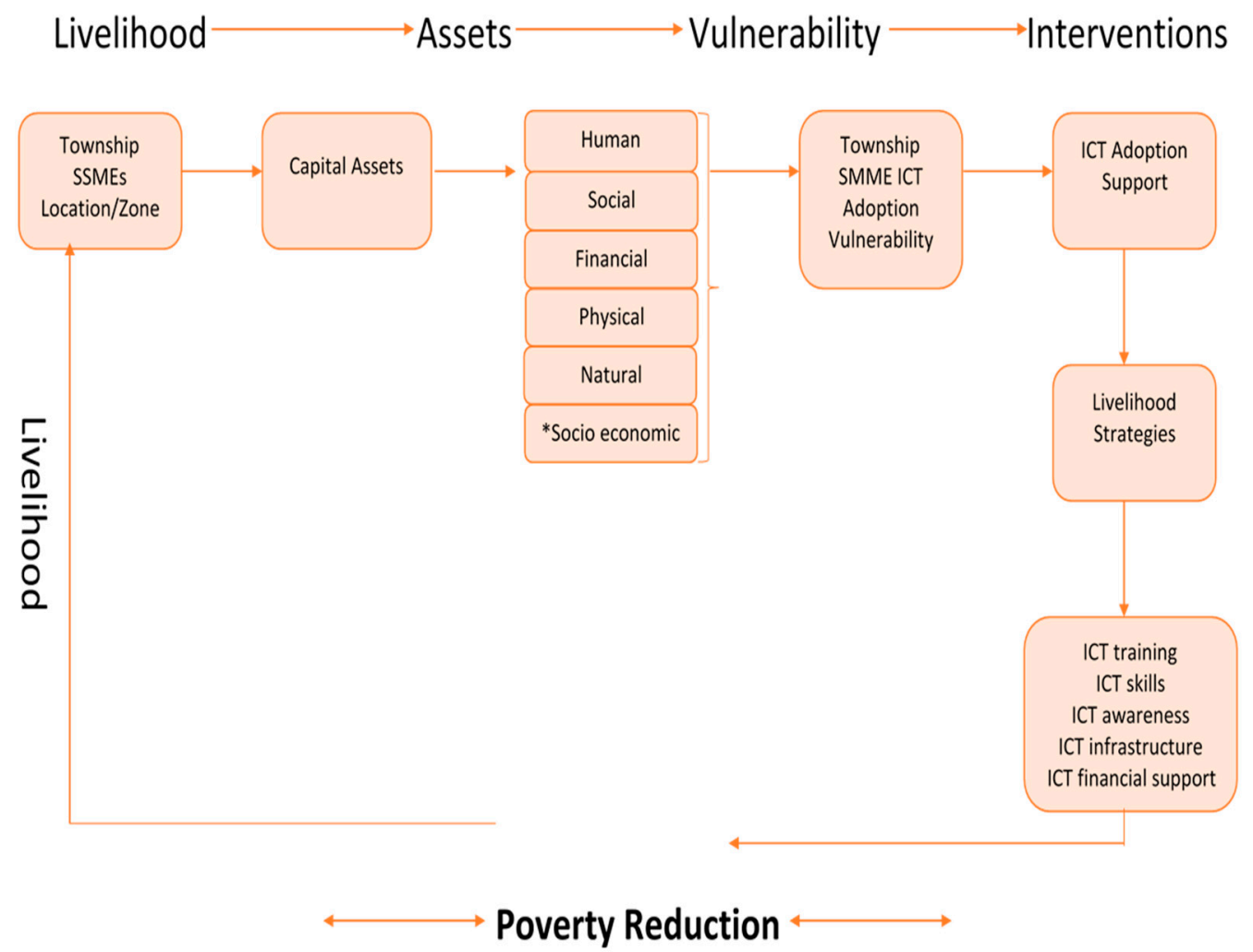

Figure 1. The sustainability livelihood framework (SLF) for township SMME ICT adoption.

The study first identified that there is a dire need to explore the livelihood of township SMME owner/manager perception/opinions towards ICT adoption. The purpose of exploring the livelihood was to gain understanding of reasons behind ICT adoption and non-adoption.

\subsubsection{First Step: Problem Definition/Livelihood of Township SMMEs}

The first step was to understand the problem that needs attention. In this study, the livelihood of township SMMEs was explored through understanding the perception/opinions of township SMMEs owners/managers towards ICT adoption. The study explored all stakeholders involved (internal and external) for successful ICT adoption for township SMMEs. A framework is defined as a structural depiction of beliefs, culture, and ideas that can provide guidance on decisions and judgement [8]. 
A conceptual framework is a system of concepts, assumptions, expectations, beliefs, and theories that supports and informs research and the relationships among them [62]. This study drew the construction of the framework from the Technology Acceptance Model (TAM), that has links for ICT adoption by SMMEs. In this step, the study focused on township SMME owner/managers' characteristics in order to underpin the perceptions/opinions of the utilisation of ICT adoption by SMME owners/managers. It was necessary to underpin SMME owner/manager perception/attitude for the intention to adopt ICT because this perception/attitude leads to their intention to adopt and can also determine their level of adoption. This theory assisted in underpinning the level of ICT adoption, ascertaining to what extent ICTs are being adopted and used by SMMEs, and the reasons thereof. The TAM focused on the SMME owners' perception/attitude for behavioural intentions towards ICT adoption, meaning that ICT adoption is linked to ease of use and usefulness. When ICT is perceived as complex by township SMME owners/managers, the chances are that they are not going to adopt nor utilise these ICTs.

\subsubsection{Second Step: SMME Location/Zone}

In this step, the study identified the location/zone where SMMEs operate. Township SMMEs are mostly regarded as informal businesses because they operate in unique locations. The location in which they operate has some influence on whether or not they adopt ICT. Reference [16] stated that some SMMEs are formally registered while others are not, and there seems to be a belief that most township SMMEs are informal, thus implying they are not registered. However, while this study acknowledges that some township SMMEs may be informal, many others are formal and may be operating below the minimum required level as categorised by the NSB Act of 1996. The location where township SMMEs operate does not regulate them as informal; there are many who are formal but lack the support, such as ICT adoption training and skills in order to be sustainable and grow. The location where SMMEs operate can be linked to the level of service they receive in order to operate their business. According to [48], the location where SMMEs operate can be influenced negatively or positively in terms of access to the commercial and professional services they can receive.

\subsubsection{Third Step: Capital Asset}

The capital asset of township SMMEs where identified using the sector, age of the business, number of employees, and annual turnover.

Sector: Township SMMEs operate in various sectors and also play a role in contributing to the crisis of unemployment that South Africa faces; a shocking high national unemployment rate of 25 per cent [62]. SMMEs in townships vary from sector to sector, and they are likely to have various views when it comes to growing their sector. For example, in terms of labour market prospects, they may have limited alternatives and views in terms of employment. Their livelihoods are not the same as the sectors operating in cities or larger sectors. Larger sectors will normally have dedicated skilled departments or individuals when considering hiring employees, whereas SMMEs may rely on the next family member to take ownership of the business, regardless of their skills or entrepreneurial competence.

Age of the business: The age of the business may be linked to the age of the SMME owner, because the age of the SMME owner may have influence over whether or not they adopt ICTs. According to the Small Enterprise Development Agency's third quarter report [48], about 54 per cent of SMMEs only operate for a period of five years, can stand operating for a period longer than five years, and are likely to survive in the next 10 to 15 years. Table 3 shows the years each business has been in operation. The age of the business was used to determine if there is any correlation with regard to SMME age classification and adopting ICT. Various studies have used the age of the business to understand and analyse the ICT adoption or utilisation from the SMME characteristics' perspective [63-65]. 
Table 3. Township SMME years in operation.

\begin{tabular}{cccccc}
\hline \multirow{2}{*}{$\begin{array}{c}\text { Classification } \\
\text { of Business }\end{array}$} & $\mathbf{1 - 1 0}$ (years) & $\mathbf{1 1 - 2 0}$ (years) & $\mathbf{2 1 - 3 0 ~ ( y e a r s ) ~}$ & $\mathbf{3 1 - 4 0 ~ ( y e a r s ) ~}$ & Total \\
\cline { 2 - 6 } & 4 & 3 & 0 & 0 & 7 \\
Small & 4 & 2 & 0 & 1 & 7 \\
Medium & 6 & 1 & 0 & 0 & 7 \\
Micro & 14 & 6 & 0 & 1 & 21 \\
Total & & & & \\
\hline
\end{tabular}

Of the 21 participants, 14 SMMEs had been in operation for less than 11 years. A total of six SMMEs had been operating for a period of 11-20 years, and only one business had been in operation for more than 30 years. ICT, in this regard, comes in as a platform which can unlock a myriad of opportunities.

Number of employees: Defining SMMEs using number of employees is problematic for SMMEs. In 2019, the south African government amended the definition of small business. The legal definition of small business was substantially updated for the first time in more than 15 years. The amended definition removed the categorization of gross asset value as a metric because it is "often inappropriate and difficult to measure". The definition includes the size of the business and the number of employees that are recognized as employed full-time, and total turnover. This categorization can be problematic when township SMMEs have no knowledge of their annual turnover, or in cases where the number of employees is seasonal, depending on the business operations.

Annual turnover: The annual turnover of the SMMEs in townships is somewhat problematic, especially if they are classified as micro businesses. The annual turnover brings in the factor of cost as an issue, thus influencing the ICT adoption process. SMMEs with a low annual turnover, meaning those that are just managing their business to pay the operational costs, may perceive ICT adoption as an expensive business decision that they cannot manage. ICT adoption is a decision that has cost implications. Most ICTs come with a price tag and decision-makers considers cost implications. Finance thus plays a vital role in SMMEs' survival and growth [66].

\section{Results and Discussion}

This study further revealed that ICT adoption is a dynamic process when considering the livelihood of township SMMEs.

From the in-depth interview and observations made at the premises where SMMEs operate, the following results were revealed:

As depicted in Table 4, only 14 types of ICTs were identified and used by township SMMEs. Interestingly, only medium businesses indicated they used a server, internet, $\mathrm{Wi}-\mathrm{Fi}$, and mobile telecom network. This could be linked to their level of ICT awareness. Again, the interesting finding was the medium business owner/manager indicating that they did not use a printer, which was associated with ICT support (maintenance and cost). However, observations showed there was, in fact, a printer in an unusable state and the participant clarified that they are no longer using it because of maintenance cost. Participant 19 mentioned, "I don't use that printer because I was told it is better to buy a new one, so I just print at a printing shop next door". The results further showed that out of 14 listed ICTs, small and micro-businesses only used 7 different types of ICTs, while medium business used 11 types. From the findings, this could also mean that the type of ICT depends exclusively on the needs of a particular business. For instance, a medium business may not use a scanner and clocking machine, while other businesses do use them. Participant 10 stated, "We use an app called Uniforce, which manages all aspect of our business, from stock, sales, accounting, I mean everything. We don't necessarily use scanners or printers". Meanwhile, participant 8 shared, "The clocking machine makes a lot of business operations easier, we depend on them most of the time. The scanner helps us, we use it more, hence we don't print anymore we just scan". 
Table 4. Type of ICTs used by township SMMEs.

\begin{tabular}{cccccc}
\hline$\#$ & ICT Type & Medium & Small & Micro & Total \\
\hline 1 & Laptop & 2 & 0 & 1 & $\mathbf{3}$ \\
2 & Printer & 0 & 0 & 1 & $\mathbf{1}$ \\
3 & Cash till machine & 1 & 0 & 1 & $\mathbf{2}$ \\
4 & Landline & 2 & 2 & 0 & $\mathbf{4}$ \\
5 & Personal computer & 3 & 3 & 1 & $\mathbf{7}$ \\
6 & Internet & 2 & 0 & 0 & $\mathbf{2}$ \\
7 & Wi-Fi & 1 & 0 & 0 & $\mathbf{1}$ \\
8 & Social media & 1 & 0 & 0 & $\mathbf{1}$ \\
9 & Applications (IS) & 3 & 3 & 1 & $\mathbf{7}$ \\
10 & Mobile phone & 3 & 2 & 4 & $\mathbf{9}$ \\
11 & Server & 1 & 0 & 0 & $\mathbf{1}$ \\
12 & Mobile telecom network & 1 & 0 & 0 & $\mathbf{1}$ \\
13 & Clocking machine & 0 & 1 & 0 & $\mathbf{1}$ \\
14 & Scanner & 0 & 1 & 1 & $\mathbf{2}$ \\
& Total & $\mathbf{2 0}$ & $\mathbf{1 2}$ & $\mathbf{1 0}$ & $\mathbf{4 2}$ \\
\hline
\end{tabular}

All 21 participants indicated having used some kind of ICT in their business operations. There was a clear indication of the commonalities of the type of ICTs used by SMMEs in townships, with mobile phones leading as the ICT of choice by all 21 participants. Although only nine participants indicated they used mobile phones for their business, it was interesting that the remaining participants (12 participants) believed that their mobile phones were for personal use and not necessarily for business operations. Furthermore, the 12 participants indicated that mobile phones are not ICTs for business operations, even though they do use them for business calls.

Although the type of ICT varies from one business to the next, there is a clear indication that SMMEs use some kind of ICT for their business operations. One participant from a medium business indicated that they adopted special software applications, namely SAGE, for their business operations to handle their accounts. Participant 7 mentioned, "For us SAGE is a necessary applications software, because I run the payroll and the staff are getting payslips and everything and then I can also do for tax purposes and all accounting matters".

Although there is an indication of various ICTs adopted, it seems SMMEs adopt ICTs that are familiar to them, such as a mobile phones, till machines, or fixed lines. Medium and small business owners/managers indicated that they owned one or more ICT for their business, such as fixed lines and a mobile phone. Although the printer was not mentioned as an ICT used in their business, they shared that they print at other businesses within or outside the township. They could not purchase a printer for their business for various reasons, such as cost or theft of the device. Participant 5 said, "We don't need ICTs like a printer for now, we are okay. It will only cost us". Participant 17 reiterated, "Printers are very expensive and they steal them. We rather use the shop next door dedicated for a printing business".

In summary, mobile ICTs were highly used by all participants. The applications were also used (Apps) primarily from mobile phones. Reference [67] posited that there has been exponential growth in the use of mobile phones due to the ease of use. Although SMME owners/managers stated that they used fixed lines, mobile phones were viewed as the most reliable. SMMEs were adopting mobile phones because they provided them with the ability to move to broader locations [60]. Only one participant indicated they were not sure if a mobile phone is regarded as ICT, even though it was being used for business operations.

Human capital: The results show the lack of ICT knowledge and ICT skills. Township SMMEs seem to have some awareness of ICT, however, the indication revealed that there was poor ICT awareness. Participant 21 stated that "I am not using any ICT however I am using mobile phone which is mainly for personal use, but I also use the mobile phone to communicate with my customers a lot". This meant participant 21 did not view a mobile phone as a type of ICT that can be used to run 
a business. SMME owners'/managers' level of ICT education has a significant role in ICT adoption. Sustainability livelihood recognises the importance of education as an asset, and that has a positive impact on ICT education for township SMMEs. ICT education can encourage better ICT awareness, provide guidance on the type of ICT to adopt and not to adopt. However, it is also worth noting that other factors may hinder the ICT adoption process, even if township SMME owners/managers acquire ICT skills. An example is the case of ICT infrastructure not being adequate. If the ICT infrastructure is not addressed, township SMMEs may still face challenges with regard to ICT adoption.

Proposition 1: ICT skills should be acquired and tailor-made specifically for township SMMEs, to enable them to better their educational information and improve their livelihood. This study proposes that ICT skills must be prioritised to educate and upskill township SMMEs on the adoption of ICT for their businesses.

Social capital refers to social resources that township SMMEs owners/managers can receive support from in order to achieve their livelihood. The support that is required may be from various agencies geared towards ICT adoption in order to sustain and grow SMMEs. Although there is no unanimity among the different meanings of social capital, it can be any social group or stakeholder that collaborates towards a common goal or interest. Social capital for township SMMEs can be derived from both internal and external actors, that is, employees, customers, and other agencies, such as suppliers directly or indirectly linked with township SMMEs. This is delicate because it has the power to contribute directly to the growth of the business and increase employability. SMME owners may find it challenging if they are not responding to competitive pressure; in particular, their competitors who are adopting ICTs may gain better competitive advantage and also have access to compete globally and have a better market entrance. Participant 3 mentioned, "I will adopt because competition from others is rising and they are ahead of us because they use ICTs". They also shared that an ICT skill is an important factor towards successful adoption. Participant 11 said, "if it will grow my business and specifically improve business services, yes I can adopt".

Proposition 2: The social resources can be gained through the support from government and various stakeholders. The government must create opportunities such as bridging the digital divide in townships. ICT support is necessary to encourage ICT adoption. The adoption of ICT will create opportunities to utilise ICTs. ICT skills can enhance business operations. This will then encourage the township SMMEs together with external stakeholders, such as suppliers and customers, to use ICT for a common goal that will add to the productivity or growth of the business.

Natural capital is the environment or the land which the SMMEs use to generate livelihood means. This must be viewed as a dynamic process because it is not constant and may continue to change depending on circumstances. There have been various interventions and efforts made by the South African government in this regard. Township SMMEs have alluded that one of the factors that inhibits them from ICT adoption is the poor ICT infrastructure in townships. Participant 1 said, "sometimes I access the internet here in Soweto, but many times at Cresta where we have another office". Participant 3 added, "here is a bit hectic, for google I access it at Maponya Mall, else mostly I buy data. I never use Wi-Fi; it is so bad I stopped the contract I had". It is necessary to address such factors before establishing other interventions.

Proposition 3: SMMEs operating in townships require land that is appropriate for business operations. They operate in areas that are not visible to consumers and suppliers. The business premises must be structured appropriately. Land that does not allow access to fibre for better connectivity will be a barrier towards ICT adoption. Land infrastructure must be attended to by the government; this will also encourage sustainability and growth of the business.

Physical capital describes the basic infrastructure, such as ICT infrastructure, that is required to encourage ICT adoption. Township SMMEs are owned by individuals and managed by them, unlike larger enterprises, where their ICT divisions may be outsourced or found to be within the businesses, such as an ICT department dedicated to supporting a business. The reality is that township SMMEs do not have the luxury to have a dedicated ICT support department, therefore, the support required 
must be formulated to accommodate their individual needs. Although participants were from various locations/zones in townships, they all possessed some kind of ICT, either hardware or software, which they used to operate their businesses. This does not mean the ICTs they owned were the correct ones to be used to grow and sustain their business. Some were not even fully utilised. Some SMMEs were not familiar with ICTs available on their mobile devices, and issues of trust also revealed that SMME owners were not adopting certain ICTs because they did not have the knowledge on how to use ICTs such as mobile banking. Participant 3 said, "I don't even know what are the good ICTs for my kind of business, I just use what I know of like Music download, google or sometimes excel". Participant 6 also mentioned, "Well I don't know of any other that can be suitable for my business, no idea, honestly".

Proposition 4: Similar to the natural capital, township SMMEs require ICT infrastructure that will enable them to access ICT. Connectivity in townships is a challenge when considering access to ICTs such as the internet. Government and stakeholders must address the issue of connectivity to add confidence and better service to SMMEs, suppliers, and customers. The physical capital, such as the type of ICT used, which mostly depends on the level of ICT access, needs attention. There should be an intervention with regard to ICT, such as software that can be used by township SMMEs. An example of such software can be cloud computing, which was not mentioned by many SMMEs.

Financial capital: The financial capital of township SMMEs is one asset that requires attention. Township SMMEs need financial support that can be used towards ICT adoption, such as ICT skills or training, in order to achieve their required livelihood. It was evident from all participants that there was no financial planning geared towards ICT adoption or support. Cost was one of the factors indicated as a reason for non-adoption. Of the participants, 20 said that "the cost of ICTs is a crucial factor influencing whether they would adopt ICTs". Participant 17 stated that "It's cost-financially it is very costly and it limits you". Participant 9 mentioned, "It is a cost, ICTs are not that cheap, cost is one of the main issues when it comes to success of our business, we cannot spend on ICTs that will not work". Given that borrowing is one of the most frequently used tools for acquiring assets, there is significant scope to discuss the importance of loans as a financial asset, its real impact on income generation, or its usefulness for people in the worst conditions.

Proposition 5: For township SMMEs to adopt ICTs, there should be ICT financial support. The financial support should directly go into investing in ICT education. Township SMMEs require ICT skills and this can be attained by investing in ICT education/training. Financial support is recommended to assist township SMMEs in making better decisions on ICT adoption. Acquiring ICT skills through training will benefit township SMMEs and improve decision-making that has financial implications for the businesses. The use of ICTs can increase their income, which can, in turn, encourage growth and create employment. The adoption of ICTs will improve efficiency and alleviate the time that SMME owners/managers use to travel from one location to the next, even outside the township in search of better connectivity. This may redirect the expenditure to better their financial status. ICT financial support is critical and must be addressed.

Socio-economic capital: South Africa, like many other developing countries, has its own share of socio-economic challenges. The challenges faced by township SMMEs are earned from the history of the country; to overcome the socio-economic challenges faced by township SMMEs a concerted effort is required from all parties involved. For South Africa to address some of its socio-economic challenges, such as the high unemployment rate, there is a desperate need to pay attention to SMMEs. However, the SMMEs themselves need to address their own socio-economic capital. Participants shared that they opted not to use a printer because they had experienced crime in the area in the past. Participant 19 mentioned that "I am not using a printer anymore; they stole it twice so I rather go to the printing shop next door". It seems even if they can afford ICTs such as printers, laptops, or desktops, the level of crime determines if they will adopt or not adopt them full time for their business.

Proposition 6: The socio-economic capital, such as crime rates, poverty, and unemployment, affect township SMMEs. Findings revealed that SMMEs have indicated that one of the factors for non-adoption was the issue of crime. For example, SMMEs mentioned they did not adopt ICTs because 
the crime rate is high in townships. This study suggests that the livelihood of township SMMEs can improve if socio-economic challenges in townships are addressed. This socio-economic capital in townships needs to be addressed to encourage best business practices for township SMMEs and emphasise growth and sustainability. The government must increase the pace of township economic support by best positioning the support towards ICT adoption by SMMEs.

\subsection{Vulnerability Context}

As previously alluded, the sustainability approach uses a "people-centred approach"; what should be the focus is what happens to the township SMME group and how they relate with other actors, including what livelihood strategies to use. The empirical data analysis revealed the type of SMME owners from their demographic data (SMME owner characteristics).

Vulnerability is characterised as insecurity in the well-being of individuals, households, and communities in the face of changes in the external environment in which they live. People move in and out of poverty, and the concept of vulnerability captures the processes of change better than poverty line measurements. Vulnerability has two facets: an external side of shocks, such as economic inflation, seasonality-especially because township SMMEs are dynamic and may be affected by technological trends - the way ICTs are used for business operations, and critical trends; and an internal side of defenselessness caused by lack of ability and means to cope with these. The vulnerability context includes poor ICT access in the context of township SMMEs; they may move from one location/zone to another because of poor access to Wi-Fi. Others may not adopt ICTs because of fear of theft or crime. These factors must be analysed and understood, because they have the potential to affect the township SMMEs and may hinder successful ICT adoption, thus affecting the sustainability of their livelihood.

\subsection{ICT Support Interventions}

In order for township SMMEs to achieve desirable outcomes, it is important to identify the kind of support required. The literature has shown that township SMMEs are not a one-size-fits-all; they are unique and require interventions that will be of benefit to them. The results revealed that there were various factors that encouraged the adoption and the non-adoption of ICTs. The perception or attitude towards ICT adoption revealed that township SMME owners/managers are vulnerable when it comes to ICT adoption. The type of support required stems from ICT skills, ICT awareness, ICT infrastructure, and ICT cost. All of these are hindrances towards growth and sustainability, thus affecting the livelihood of township SMMEs negatively and not allowing growth and development.

The consequences of an ICT-support programme embedded in an intervention to support township SMMEs also noted that this strategy had limited success. In the first place, consistent with the findings of [10], a number of SMMEs were not even aware of available ICT support or interventions. The lack of awareness partly resulted from a mismatch in the nature of communication between stakeholders on the one hand and SMMEs on the other hand. The problem of a lack of awareness of support services by SMMEs is persistent in information systems literature, as highlighted in a number of studies $[68,69]$. It is necessary to revisit all ICT support structures and interventions in order to ensure they are visible and fully utilised to address the livelihood of township SMMEs with regard to ICT adoption.

\section{Conclusions}

The SLF is necessary to unveil the livelihood analysis of township SMMEs. The livelihood of township SMMEs can only be improved when there is an in-depth analysis of the challenges faced by townships, due to the impact of the past that has largely affected the current status in townships. This study revealed how township SMMEs can gain sustainable livelihood when considering all livelihood assets, including vulnerability context. The type of support required stems from ICT skills, ICT awareness, ICT infrastructure, and ICT cost. All of these are hindrances towards growth and sustainability, thus affecting the livelihood of township SMMEs negatively and not allowing growth and development. 
The results showed that township SMMEs are not a one-size-fits-all; they are unique and require interventions that will be of benefit to them. From the empirical data analysis, results show that there were various factors that encouraged the adoption and the non-adoption of ICTs. The perception or attitude towards ICT adoption revealed that township SMME owners/managers are vulnerable when it comes to ICT adoption.

The general findings were that there is a need to address ICT issues with SMMEs operating in the townships. Their perception of this study was that of revived hope. They shared that it was their first encounter engaging in ICT conversation, which ignited hope in them. Generally, township SMMEs believe that ICTs can help them grow and sustain their businesses, and they also acknowledged the fact that they need interventions and ICT support from government and all stakeholders.

\subsection{Research Limitations}

First, the data were only sourced in one province (Gauteng) out of nine provinces in South Africa. This study was also limited to 21 SMME owners/managers, from whom data were sourced from seven locations/zones in Soweto. It is important to note that Soweto is the larger township in South Africa, with over 25 locations/zones. Secondly, the ICT adoption sustainability livelihood framework is limited because it only focuses on the perceptions/opinions of SMME owners/managers. Further research is required to gain the perception/opinion of the customers, suppliers, and government within the SMME setting with regard to ICT adoption by township SMMEs.

\subsection{Suggestions for Future Research}

The township settings in all nine provinces of South Arica share similarities, therefore this research can be used in other settings, such as city SMMEs and rural SMMEs, to validate the conceptual framework. The key participants in this study were SMMEs operating in the townships with regard to ICT adoption. Further research can include larger enterprises operating in the townships with regard to their perception/opinion towards ICT adoption. The key role players were township SMME owners/managers. Further research can include suppliers, customers. and stakeholder's views on ICT adoption in the townships.

The study made propositions to guide township SMMEs owners/managers and policymakers on factors to consider when encouraging ICT adoption. Further research can investigate the guidelines' effectiveness towards sustaining the livelihood of township SMMEs.

Author Contributions: S.B. and C.M. worked jointly on the development of the study and the research methodology. The data collection and data analysis was done by S.B. All authors have read and agree to the published version of the manuscript.

Funding: This research received no external funding.

Conflicts of Interest: The authors declare no conflict of interest.

\section{References}

1. Rungani, E.C.; Potgieter, M. The impact of financial support on the success of small, medium and micro enterprises in the Eastern Cape Province. Acta Commercii 2018, 18, a591. [CrossRef]

2. Leboea, S.T. The factors influencing SME failure in South Africa (online). MBA, University of Cape Town. 2017. Available online: https://open.uct.ac.za/bitstream/item/28704/thesis_ReferencelistPage210com_2017_ leboea_sekhametsi_tshepo.pdf?sequence $=1$ (accessed on 30 September 2017).

3. Nieman, G.; Nieuwenhuizen, C. Entrepreneurship: A South African Perspective; Van Schaik Publishers: Pretoria, South Africa, 2010.

4. Harris, R.W. Information and Communication Technologies for Poverty Alleviation. ePrimers for the Information Economy, Society and Policy; The United Nations Development Programme's Asia-Pacific Development Information Programme (UNDP-APDIP): Kuala Lampur, Malaysia, 2004.

5. Mbuyisa, B.; Leonard, A. The role of ICT use in SMEs towards poverty reduction: A systematic literature review. J. Int. Dev. 2017, 29, 159-197. [CrossRef] 
6. Johnston, K.; Jali, N.; Kundaeli, F.; Adeniran, T. ICT for the broader development of South Africa: An analysis of literature. Electron. J. Inf. Syst. Dev. Ctries. 2015, 70, 1-22. [CrossRef]

7. Thapa, D.; Sæbø, Ø. Exploring the link between ICT and development in the context of developing countries: A literature review. Electron. J. Inf. Syst. Dev. Ctries. 2014, 64, 1-15. Available online: https://www.ejisdc.org/ojs2/index.php/ejisdc/article/view/1332 (accessed on 1 May 2018). [CrossRef]

8. Zewge, A.; Dittrich, Y.; Bekele, R. Systematic mapping study of information communication technology research for agriculture: The case of developing countries. Electron. J. Inf. Syst. Dev. Ctries. 2017, 82, 1-25. Available online: http://www.is.cityu.edu.hk/staff/isrobert/ejisdc/82-2.pdf (accessed on 2 March 2018).

9. Ismail, R.; Jeffery, R.; van Belle, J.P. Using ICT as a value adding tool in South African SMEs. J. Afr. Res. Bus. Technol. 2011, 2011, 1-12. [CrossRef]

10. Pillay, P. Barriers to Information and Communication Technology (ICT) Adoption and Use amongst SMEs: A Study of the South African Manufacturing Sector. Master's Thesis, University of the Witwatersrand, Johannesburg, South Africa, 2016.

11. Mathu, K.; Tlare, M.T. The impact of IT adoption in SMEs supply chains: A case of Gauteng and Free State provinces of South Africa. S. Afr. J. Bus. Manag. 2017, 48, 63-71. [CrossRef]

12. Turpin, M. Assessing South African ICT4D research outputs: A journal review. S. Afr. Comput. J. 2018, 30, 108-127. [CrossRef]

13. Cant, M.C.; Wiid, J.A.; Hung, Y. Internet-based ICT usage by South African SMEs: Are the benefits within their reach? Probl. Perspect. Manag. 2015, 13, 444-451.

14. Marnewick, C. Information and communications technology adoption amongst township micro and small business: The case of Soweto. S. Afr. J. Inf. 2014, 16. [CrossRef]

15. Agwu, E.; Murray, P.J. Relevance of Information Technology in the effective Management of the selected SMEs in LAGOS State of Nigeria. Acad. Strateg. Manag. J. 2018, 17, 1-15.

16. Department of Trade and Industry (DTI). Business in the Information Age: International Benchmarking Report; Department of Trade and Industry: London, UK, 2008.

17. Mtshali, M.; Mtapuri, O.; Shamase, S.P. Experiences of black-owned small medium and micro enterprises in the accommodation tourism-sub sector in selected Durban townships, KwaZulu-Natal. Afr. J. Hosp. Tour. Leis. 2017, 6, 130-141.

18. Ramchander, P. Township tourism: Blessing or blight? The case of Soweto in South Africa. In Cultural Tourism: Global and Local Perspectives; Richards, G., Ed.; Haworth Press: New York, NY, USA, 2007; pp. $39-67$.

19. Ntsika Enterprise Promotion Agency Annual Review; State of Small Business Development SA Johannesburg: Ntsika, South Africa, 2001.

20. Ngwenyama, O.K.; Morawczynski, O. Factors Affecting ICT Expansion in Emerging Economies: An Analysis of ICT Infrastructure. Inf. Technol. Dev. 2009, 15, 237-258. [CrossRef]

21. World Bank Study. Economics of South Africa Townships, Special Focus on Diepsloot; Worldbank Group: Washington, DC, USA, 2014.

22. Sanchez, D. Transformation in Small Medium and Micro Enterprises; Human Science Research Council Race Relations Press: Cape Town, South Africa, 2008.

23. Njiro, E.; Mazwai, T.; Urban, B. A Situational Analysis of Small Business and Enterprises in the Townships of the Gauteng Province of South Africa. Paper Presented at the 1st International Conference; University of Johannesburg: Johannesburg, South Africa, 2010.

24. Harrison, P.; Harrison, K. Soweto: A study in socio-spatial differentiation. In Changing Space, Changing City, Johannesburg after Apartheid; Harrison, P., Gotz, G., Todes, A., Wray, C., Eds.; Wits University Press: Johannesburg, South Africa, 2014.

25. Bloch, R.; Kesper, A. Supporting the Small and Medium Manufacturing Sector in the Western Cape; Council for Scientific and Industrial Research: Pretoria, South Africa, 2000.

26. Republic of South Africa. National Small Business Act No. 102 of 1996. Pretoria: Government Printer. 1996. Available online: http://www.thedti.gov.za/sme_development/docs/act.pdf (accessed on 21 August 2017).

27. Falkena, H.I.; Abedian, M.; Blottnitz, C.; Coovadia, G.; Davel, J.; Madungandaba, E.; Masilela, S.; Rees, S. SMEs' Access to Finance in South Africa, A Supply-Side Regulatory Review, The Task Group of the policy Board for Financial Services and Regulation. 2001. Available online: www.finance.gov.za/documents/smes (accessed on 3 May 2016). 
28. Brown, B.; Brown, I. Towards a research framework for a human development based "bottom of the pyramid" ICT development strategy in South Africa. In Proceedings of the 17th European Conference on Information Systems, Verona, Italy, 8-10 June 2009.

29. Tustin, D.H.; Ligthelm, A.A.; Martins, J.H.; Van Wyk, H.D.J. Marketing Research in Practise; University of South Africa: Pretoria, South Africa, 2005.

30. Tustin, D.H.; De Clercq, B.; Venter, J.M.P. The Impact of Taxation on SME Retailers in Gauteng; Unisa Press: Pretoria, South Africa, 2006.

31. Ranyane, K.A. Survivalist entrepreneurship: An income generating alternative for the unemployed populace. Mediterr. J. Soc. Sci. 2015, 6, 301. [CrossRef]

32. Chalera, C.S. An Impact Analysis of South Africa's National Strategy for the Development and Promotion of Smmes; University of Pretoria: Pretoria, South Africa, 2007; Available online: https://www.researchgate.net/ publication/259673776_Overview_and_Performance_of_the_SMMEs_Sector_in_South_Africa (accessed on 6 March 2019).

33. Mulugeta, E. Underlying Courses of Micro and Small Business Failures in Addis Ketema Sub City: A Case Study. Master's Thesis, Addis Ababa University Press, Ethiopia, East Africa, 2008.

34. Morris, M.H. Entrepreneurial Activity in the Third World Informal Sector: The View from Khayelisha. Int. J. Entrep. Behav. Res. 1996, 2, 59-76. [CrossRef]

35. Rogerson, C.M. Urban poverty and the informal economy in South Africa's economic heart lands. Environ. Urban. 1996, 8, 167-179. [CrossRef]

36. Lekhanya, L.M. Rural Entrepreneurship Promotional Strategy in South Africa: Concepts, Practice and Theories; Virtus Interpress: Gagarina, Ukraine, 2016.

37. Mrasi, A.; Mason, R.B.; Jere, A. Critical skills and knowledge to succeed in the township liquor retail industry. J. Bus. Retail Manag. Res. 2018, 12. [CrossRef]

38. Myeko, Z.; Iwu, C.G. Obstacles faced by African Copreneurs in Black Townships of the Western Cape, South Africa. J. Rev. Glob. Econ. 2019, 8, 1-11. [CrossRef]

39. Mbonyane, B.; Ladzani, W. Factors that hinder the growth of small businesses in South African townships. Eur. Bus. Rev. 2011, 23, 550-560. [CrossRef]

40. Mukwarami, J.; Tengeh, R.K.; Iwu, C.G. Success factors of immigrant-owned informal grocery shops in South African townships: Native shop-owners' account. J. Distrib. Sci. 2018, 16, 49-57. [CrossRef]

41. Bhorat, H.; Asmal, Z.; Lilenstein, K.; van der Zee, K. SMMES in South Africa: Understanding the Constraints on Growth and Performance; Development Policy Research Unit Working Paper 201802; DPRU, University of Cape Town: Cape Town, South Africa, 2018.

42. Moos, M.; Sambo, W. An exploratory study of challenges faced by small automative business in townships: The case of Garankuwa, South Africa. J. Contemp. Manag. 2018, 14, 467-494.

43. Makhitha, K.M. Challenges impacting on small independent retailers performance in Soweto, Johannesburg in South Africa. Invest. Manag. Financ. Innov. 2016, 13, 258-266. [CrossRef]

44. Phikiso, Z.; Tengeh, R.K. Challenges to inter-family succession in South African townships. Acad. Entrep. J. 2017, 23, 1-3.

45. Asgarkhani, M.; Young, A. Industry view of ICT roles and skills in Canterbury. In Proceedings of the 1st Annual Conference of Computing and Information Technology Research and Education, Dunedin, New Zealand, 6-9 July 2010.

46. Apulu, I. Developing a Framework for Successful Adoption and Effective Utilisation of ICT by SMEs in Developing Countries: A Case Study of Nigeria. Ph.D. Thesis, University of Wolverhampton, Wolverhampton, UK, 2012.

47. Irefin, I.A.; Abdul-azeez, I.A.; Tijani, A.A. An investigative study of the factors affecting the adoption of information \& communication technology in small \& medium scale enterprises in nigeria. Aust. J. Bus. Manag. Res. 2012, 2, 1-9.

48. SEDA (Small Enterprise Development Agency), 1st Quarter. SMME Quarterly Update. South Africa; SEDA (Small Enterprise Development Agency): Pretoria, South Africa, 2018.

49. Statistics South Africa. Unemployment Rates. 2018. Available online: www.statssa.gov.za (accessed on 29 May 2019).

50. Alvi, A.M. Manual for Selecting Sampling Techniques in Research; University of Karachi, Iqra University: Karachi, Sindh, Pakistan, 2016. 
51. Neves, D.; du Toit, A. Money and Sociality in South Africa's Informal Economy. Africa 2012, 82, 131-149. [CrossRef]

52. Taborda, J. South Africa Unemployment Rate. 2016. Available online: www.tradingeconomics.com (accessed on 10 July 2017).

53. Bisseker, C. SMEs: Stop the Failure Rate. 2014. Available online: http://www.financialmail.co.za/features/ 2014/05/15/smes-stop-the-failure-rate (accessed on 11 June 2016).

54. Wagner, E.T. Five Reasons 8 out of 10 Businesses Fail. 2015. Available online: http://www.forbes.com/sites/ ericwagner/2013/09/12/five-reasons-8-out-of-10-businessesfail/ (accessed on 15 September 2016).

55. Malebana, M.J. Knowledge of entrepreneurial support and entrepreneurial intention in the rural provinces of South Africa. Dev. South. Afr. 2017, 34, 74-89. [CrossRef]

56. DFID. Achieving Sustainability: Poverty Elimination and the Environment, Strategies for Achieving the International Development Targets; Department for International Development: London, UK, 2000.

57. Carney, D. Sustainable livelihoods. Sustainable Livelihoods: What contribution can we make. In Proceedings of the Department for International Development's Natural Resources Advisers' Conference, London, UK, 1 July 1998.

58. Davies, S. Adaptable Livelihoods: Coping with Food Insecurity in the Malian Sahel; Macmillan: London, UK, 1996.

59. Soussan, J. Understanding livelihood processes and dynamics: Livelihood-policy relationships in South Asia. 2000. Available online: https://www.semanticscholar.org/paper/Understanding-Livelihood-Processesand-Dynamics-in/73b9cc7bcd9fd193072f2e0a4debf9774198bbcb (accessed on 1 March 2020).

60. Ashley, C.; Diana, C. Sustainable Livelihoods: Lessons from Early Experience; Department for International Development Vol. 7. No. 1.; British Library: London, UK, 1999.

61. Miles, M.B.; Huberman, A.M.; Saldana, J. Qualitative Data Analysis-A Methods Sourcebook; SAGE Publications, Inc.: London, UK, 2019.

62. Statistics South Africa. Quarterly Labour Force Survey; Statistics South Africa: Pretoria, South Africa, 2015.

63. Ibrahim, A.M. Strategizing Small and Medium Enterprises Development through ICTrelated Innovations Adoption: Moderating Influence of Gender, Age and Experience. 2018. Available online: dx.doi.org/10. 21831/informasi.v48i1.18417 (accessed on 1 March 2020).

64. Mpofu, K.; Gono, S. Exploring ICT Adoption by SMEs in Southern Africa; LSBM Working Paper Series 1; Centre for Research and Enterprise: Pretoria, South Africa, 2016.

65. OECD. Enhancing the Contributions of SMEs in a Global and Digitalised Economy; OECD Publishing: Paris, France, 2017. Available online: http://www.oecd.org/cfe/leed/1918307.pdf (accessed on 3 February 2019).

66. Chan, S.H.; Lin, J.J. Financing of micro and small enterprises in China: An exploratory study. Strateg. Chang. 2013, 22, 431-446. [CrossRef]

67. Ahad, T. Exploring the usage of the mobile phones by SMEs in the achievement of Vision 2020 Goals. J. Mob. Technol. Knowl. Soc. 2016. [CrossRef]

68. Aker, J.C.; Mbiti, I.M. Mobile Phones and Economic Development in Africa. J. Econ. Perspect. 2010, 24, 207-232. [CrossRef]

69. Mitrovic, Z.; Bytheway, A. Awareness of e-government related small business development services in Cape Town. Electron. J. Inf. Syst. Dev. Ctries. 2009, 39, 1-14. [CrossRef]

(C) 2020 by the authors. Licensee MDPI, Basel, Switzerland. This article is an open access article distributed under the terms and conditions of the Creative Commons Attribution (CC BY) license (http://creativecommons.org/licenses/by/4.0/). 